\title{
CYPRUS AND THE GREAT POWERS AN EVALUATION OF RUSSIAN-CYPRIOT RELATIONS IN THE NEW EASTERN MEDITERRANEAN ENVIRONMENT
}

Michalis Kontos ${ }^{\star}$

\author{
DOI 10.24833/2073-8420-2019-4-53-17-27
}

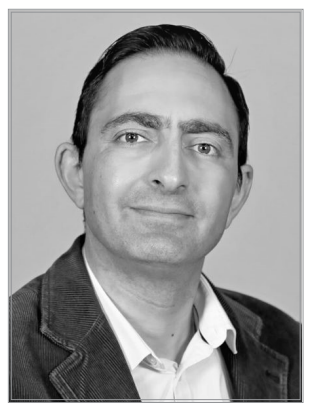

Relations between the Russian Federation and the Republic of Cyprus have been traditionally close. However, some recent systemic developments seem to undermine their solid foundations. This article examines the contemporary international system and, especially, the regional sub-system of the Eastern Mediterranean in order to trace systemic changes that may affect relations between the countries under examination. The analysis of the Russian-Cypriot relations focuses on the potential effects of the international systemic changes on each one of their three main pillars: economic, diplomatic and cultural relations.

\section{Introduction}

$\mathrm{R}$ elations between the Russian Federation and the Republic of Cyprus have been traditionally close. The main pillars of this partnership are the following:

1. Connections of economic nature (especially the business activity of the vibrant Russian community in Cyprus, the registration of Russian offshore companies in Cyprus and Russian deposits in Cypriot banks, as well as the reliance of Cypriot tourism on the Russian market).

2. Diplomatic relations, especially Russia's policy on the Cyprus problem (we may underline Moscow's support of Nicosia's positions in the UN Security Council).

3. Cultural relations (predominantly based on the common Christian Orthodox origins).

However, some recent developments seem to undermine the solid foundations of
Russian-Cypriot relations: the rapid progress in Russian-Turkish relations, in conjuncture with the role that Cyprus has recently assumed in the US agenda for the Eastern Mediterranean, seem to create the conditions for the development of diverging interests and, in the long-term, conflicting choices and policies. This hypothesis is underpinned by two sets of developments:

1. The deterioration of US-Russian relations since the eruption of the Ukrainian crisis and the growing competition between Russia and NATO in Eastern Europe.

2. The stalemate in the negotiations for the solution of the Cyprus problem and the rising tensions in the Eastern Mediterranean due to Ankara's disapproval of Cyprus' quest for offshore energy resources.

At first sight, and taking into account the strategic importance of these issues for the in-

\footnotetext{
* Michalis Kontos, Assistant Professor, Department of Politics and Governance, School of Law, University of Nicosia, Cyprus.

e-mail: kontos.m@unic.ac.cy

ORCID ID: 0000-0002-0718-1145
} 
terested parties' foreign policy agendas, we might assume that a dramatic re-configuration of bilateral relations among the quartette under examination may take place in the near future. In other words, renewed relations between Russia and Turkey may cause further development of dealings between the US and Cyprus and vice versa, while traditional relations between Moscow and Nicosia will wane. However, some other factors tend to mitigate this possibility. This tag-of-war between tendencies and counter-tendencies may facilitate the development of a particularly complex framework of interrelations, where deciding who is your friend and who your foe will be hindered by a significant degree of opaqueness. In this article, we shall take a systemic approach in order to define the factors that tend to enhance or undermine bilateral relations between Russia and Cyprus, based on the following research questions:

1. How does the contemporary international environment affect relations between the US, Russia, Turkey and Cyprus?

2. To what extend are these reconfigurations (improved Russian-Turkish relations and the new role of Cyprus in the US agenda for the Eastern Mediterranean) mutually exclusive?

3. How deep and resilient are the relations between Russia and Cyprus in view of the new strategic challenges? Which are the determinants that define the depth and quality of this bilateral relationship in the context of the new strategic environment?

In the first part, we shall examine the contemporary international system and, especially, the regional sub-system of the Eastern Mediterranean and the broader Middle East in order to trace systemic changes that may affect the bilateral relationship under examination. Following that, we shall focus on the Russian-Cypriot relations by examining the potential effects on each one of the three pillars (economic, diplomatic and cultural relations). Finally, we will proceed to a comprehensive evaluation of the current state of affairs of Russian-Cypriot relations, with reference to tendencies that may affect and/or define their evolution.

\section{Systemic Changes and Structural Effects: The "Moving tectonic Plates" of the International System}

At the initial stages of the post-Cold War period, the US, as the only remaining superpower, enjoyed an unprecedented comparative advantage of power towards its (potential) future competitors. However, unipolar systems were stillborn, as they tend to expose the global hegemon to the perils of overextension that weakens national power over the longer term ${ }^{1}$. For the US, this became evident after Al Qaeda's terrorist attacks on 11 September 2001, and Washington's subsequent decisions to engage in two costly wars, the intervention in Afghanistan in 2001 and the invasion of Iraq in $2003^{2}$. The overstretch of US capabilities proved to be fatal: the war adventures in Afghanistan and Iraq became the turning points of a two-decades-lasting course of strategic expansion. As Gilpin would argue, "marginal costs of further expansion" proved to be "greater than marginal benefits". ${ }^{3}$ Stephen Walt had prophetically underlined in 2005 that the shift toward unilateral and hegemonic strategic options in the Middle East (evident during G. W. Bush' presidency) would jeopardise US international position and prestige in the long term:

"States that seek to challenge US primacy will look for windows of opportunity. The temptation to exploit these windows will increase even further when they enable other States to alter the balance of power in some tangible and enduring way. Defying the US is inherently risky, but it makes more sense to run these risks if the act of defiance itself may place the state in question in a fundamentally stronger strategic position" ${ }^{\prime 4}$.

In the meantime, the increasingly expansionist post-Cold War policies of Western institutions in Eastern Europe disturbed the Russian Federation and called for a more active balancing strategy in its own backyard. Especially the accession of former Soviet satellites to NATO and Ukraine's flirt with the European Union urged Russia to project its own muscle in order to deter Western influence from being established in a "safety zone" ranging from the Baltic

\footnotetext{
${ }^{1}$ K. N. Waltz, 'Structural Realism After Cold War,' International Security 25 (2000): 13. See also Kennedy, The Rise and Fall of Great Powers.

2 S. M. Walt, 'The End of Hubris and the New Age of American Restraint,' Foreign Affairs, Vol. 98. No. 3 (May/June 2019), 28.

3 R. Gilpin, War and Change in World Politics, (Cambridge: Cambridge University Press, 1981), 106-107.

4 S. Walt, Taming American Power, (New York: W. W. Norton \& Company, 118).
} 
Sea to the Black Sea and Caucasus ${ }^{5}$. After the annexation of Crimea in 2014, a spiral of hostile interactions made Russia's relations with the West worse than at any time since the Cold War6.

For the needs of our analysis these developments must be associated with the broader strategic retreat of the US from the Middle East, which was sealed by the withdrawal of US military forces from Iraq in 2011. The attempt to impose a hegemonic pattern of relations in the greater Middle East came to an inglorious end, as Washington was no more willing to pay the price of regional dominance in this volatile region $^{7}$. Consequently, American disengagement created perceptions of a power vacuum in the Middle East; real or imagined, the power vacuum transformed, or contributed to the transformation of the behavior of several actors ${ }^{8}$. One such case was the transformation of Turkey's foreign policy, especially since 2010 onwards. Of course Turkey's partial disengagement from its commitments toward its Western allies and its quest for an independent (Neo-Ottoman style) foreign policy agenda, could be better explained at the individual and state levels of analysis, due to the catalytic role of the Justice and Development Party's policies and President Recep Tayyip Erdoğan's Islamist revisionism9. How- ever, systemic factors cannot be omitted when trying to explain this shift; it would be rather erroneous to assume that the Turkish agenda for the Middle East would have taken such a revisionist form if the US had retained its directly interventionist strategy after 2011, especially in relation with $\operatorname{Iraq}^{10}$. Another case indicative of the systemic outcomes of the US partial disengagement from the Middle East after 2011 was the meteoric increase of Russian influence, as well as diplomatic and military activity, in the broader region. Russia also seems to have perceived US strategic retreat as a "carte blanche" for deeper involvement in the Middle East and the Eastern Mediterranean. The flirt between Russia and Egypt after President Mohamed Morsi's ouster and General Abdel Fatah el-Sisi's takeover was the first strong indication of this transformation ${ }^{11}$. Furthermore, Moscow's naval moves in the Eastern Mediterranean shaped a new regional naval equilibrium ${ }^{12}$. Finally, Russia's new role in the region was sealed by Moscow's military intervention in the Syrian crisis in September 2015, in support of the government of President Bashar al-Assad and the subsequent growth of Russia's aerial and naval presence in the Mediterranean ${ }^{13}$. Moscow obviously concluded that military engagement in Syria,

5 J. J. Mearsheimer, "Why the Ukraine Crisis Is the West's Fault," Foreign Affairs, Vol. 93, No. 5 (September/October 2014), 77-89. Stephen Kotkin, "Putin Returns to the Historical Pattern," Foreign Affairs, April 18, 2016. https:// www.foreignaffairs.com/articles/ukraine/2016-04-18/russias-perpetual-geopolitics, accessed on May 7, 2015. Henry Kissinger, "How the Ukraine Crisis Ends," The Washington Post, March 6, 2014. http://www.henryakissinger.com/ articles/wp030614.html, accessed on June 1, 2016.

6 S. Walt 'The End of Hubris and the New Age of American Restraint,' 28.

7 M. Kontos, "Hegemony and Balance of Power in the Middle East," Eastern Mediterranean Geopolitical Review, Issue 2 (Fall 2016), 22.

8 Ibid., 24.

9 I. I. Kouskouvelis, "The Problem with Turkey's 'Zero Problems:' Turkey, Past and Future," Middle East Quarterly, 20:1 (Winter 2013), 47-56. http://www.meforum.org/3455/turkey-zero-problems, accessed on April 24, 2019. B. Begdil, "Turkey: What Ally?" Gatestone, September 22, 2014, https://www.gatestoneinstitute.org/4715/turkey-ally, accessed on April 24, 2019. N. Stone, "Erdogan's dreams of empire are perilous to Turkey," The Guardian, December 6, 2015. https://www.theguardian. com/commentisfree/2015/dec/06/erdogan-turkey-russia-syria-foreign-policy, accessed on December 12, 2015. S. A. Cook, M. J. Kopolow, "Turkey is no longer a reliable ally," Wall Street Journal, August 10, 2016, http://www.wsj.com/articles/turkey-is-no-longer-a-reliable-ally-1470869047, accessed on April 24, 2019.

${ }^{10}$ H. J. Barkey, "Turkey's New Engagement in Iraq: Embracing Iraqi Kurdistan," United States Institute of Peace, Special Report 237, May 2010, http://carnegieendowment.org/files/USIP_SR_Turkey_Iraq.pdf, accessed on April 24, 2019.

${ }^{11}$ Col. (ret.) J. Neriah, "Egypt's Turn to Russia," Jerusalem Center for Public Affairs, October 30, 2013, http://jcpa.org/ egypts-turn-to-russia/, accessed on April 24, 2019; V. Naumkin, "Russia and Egypt's 'new partnership'," Al Monitor, February 11, 2015, http://www.al-monitor.com/pulse/originals/2015/02/moscow-cairo-relations-sisi-putin-egyptvisit.html, accessed September 19, 2015.

${ }_{12}$ Captain (ret.) T. R. Fedyszyn, "The Russian Navy 'Rebalances' to the Mediterranean," U.S. Naval Institute, 139 (December 2013), http://www.usni.org/magazines/proceedings/2013-12/russian-navy-rebalances-mediterranean, accessed on April 24, 2019.

${ }^{13}$ E. Barrett, "Letting Putin Get Away with it," Foreign Policy, January 19, 2016, http://foreignpolicy.com/ 2016/01/19/ syria-kurds-russia-sunni-arab/, accessed on March 12, 2016; H. A. Kissinger, "A Path out of the Middle East Collapse," Wall Street Journal, October 16, 2015, http://www.wsj.com/articles/apathoutofthemiddleeastcollapse1445037513, accessed on October 22, 2015. J. B. Alterman, H. A. Conley, H. Malka, D. Ruy, "Restoring the Eastern Mediterranean as a US Strategic Anchor," Center for Strategic and International Studies, 6-7. 
which became a rational choice due to the initial US disorientation regarding the Syrian civil war and Washington's decision not to proceed with a military strike against the al-Assad regime in September 2013, despite the latter's alleged use of chemical weapons which was considered as a "red line" by the Obama administration ${ }^{14}$.

In the context of the "moving tectonic plates of the international system", developments in the broader Middle East culminated to a significant convergence of interests and rapprochement between Turkey and Russia despite Turkey's NATO membership and the two countries' strong disagreements on various issues. After the downing of a Russian Su-24M by a Turkish F-16 over Syria in November 2015 and Turkey's official apology-and despite the conflicting positions of the two countries in relation with the Syrian civil war-their bilateral relations improved rapidly at various levels. The agreement for Turkey's purchase of the Russian S-400 missile defence system is the cornerstone of this unexpectedly flourishing partnership. This development convulsed NATO and drew sharp reactions from Washington, even warnings for "grave consequences", including the freezing of Turkey's efforts to acquire the F-35 jet and its expulsion from the consortium that builds the new generation of this state-of-the-art fighter ${ }^{15}$.

In parallel, while Turkey's commitment to NATO was disputed by its allies and Ankara's "zero-problems policy" was failing to deliver, ${ }^{16}$ another realignment was taking place: natural gas findings offshore Israel, Egypt and Cyprus became the main catalyst of Israel and Egypt's respective trilateral partnerships with Greece and Cyprus, despite Turkey's vehement reactions in relation with the latter's offshore sovereign rights ${ }^{17}$. These partnerships drew atten- tion by extra-regional powers with interests in the region, such as France and the US, mainly because of the activity of French and American oil and gas companies in the area. Especially the Israel-Cyprus-Greece axis, which led to an agreement for an ambitious project to create the longest underwater natural gas pipeline in the world across the Eastern Mediterranean, enjoys grave support by Washington. This support was sealed by the symbolic participation of the US Secretary of State, Mike Pompeo, in the sixth tripartite summit in Jerusalem, on 20 March 2019. ${ }^{18}$ The US interest in these developments is perceived by some analysts as an opportunity for Washington to shape the Eastern Mediterranean's economic and security environment, ${ }^{19}$ while others see it even as a potential pillar for the formation of a new, favorable balance of power, in view of Turkey's strategic re-orientation..$^{20}$ At the same time, Russia's involvement was insignificant, because energy-related developments in the Eastern Mediterranean may jeopardise Moscow's particular interests and privileged position in the European and the Turkish markets. $^{21}$

The recent introduction of a bill in the Senate of the US by Senators Robert Menendez and Marco Rubio, aiming to "promote security and energy partnerships in the Eastern Mediterranean", 22 suggests the strongest indication of the role Washington aims to assume in the region. This bill, titled "Eastern Mediterranean Security and Energy Partnership Act of 2019", underlines the role of Greece and Israel in the Eastern Mediterranean and praises their trilateral partnership, as well as Cyprus' position as a key strategic partner. It refers to the importance of natural gas findings in the Eastern Mediterranean, as well as to the dangers that Turkey's in-

14 J. Goldberg, "The Obama Doctrine," The Atlantic, April 2016, http://www.theatlantic.com/magazine/ archive/2016/04/the-obama-doctrine/471525/, accessed on June 5, 2016.

15 B. Bekdil, "Turkey: Putin's Ally in NATO?" Gatestone Institute, March 19, 2019. https://www.gatestoneinstitute. org/13882/turkey-putin-ally-nato, accessed on May 7, 2019.

${ }^{16}$ I. I. Kouskouvelis, "The Problem with Turkey's 'Zero Problems'."

${ }^{17}$ On the trilateral partnerships see Z. Tziarras (ed.), The New Geopolitics of the Eastern Mediterranean: Trilateral Partnerships and Regional Security. Re-imagining the Eastern Mediterranean Series: PCC Report, 3. Nicosia: PRIO Cyprus Centre. On Turkey's strategy to encounter Cyprus' drilling program see M. Kontos, G. Bitsis, "Power Games in the Exclusive Economic Zone of the Republic of Cyprus: The Trouble with Turkey's Coercive Diplomacy," The Cyprus Review, Vol. 30, No. 1 (Spring 2018), 51-70.

${ }^{18}$ G. N. Tzogopoulos, "A New EastMed Friendship, with US Support," BESA Center Perspectives Paper No. 1,137, April 10, 2019.

${ }^{19}$ Alterman et. al., "Restoring the Eastern Mediterranean as a US Strategic Anchor," 9.

${ }^{20}$ S. Cropsey, "U.S. Policy and the Strategic Relationship of Greece, Cyprus, and Israel: Power Shifts in the Eastern Mediterranean," Hudson Institute, March 2015, 19.

${ }^{21}$ P. Baev, "Russia Fakes Interest in Hydrocarbons in the Eastern Mediterranean," in A. Gürel, H. Tzimitras, H. Faustmann (eds.), East Mediterranean Hydrocarbons: Geopolitical Perspectives, Markets and Regional Cooperation. Report 3/2014 (Nicosia: Friedrich Ebert Stiftung, Brookings, PRIO, 2014), 38-44, 41.

22 "Eastern Mediterranean Security and Energy Partnership Act of 2019." 
tention to purchase the S-400 system from Russia poses for the US interests. Furthermore, it stresses Europe's need for energy diversification and decreasing dependence on Russia. In relation with Cyprus, the main contribution of this bill is the proposal for the removal of the prohibition of US arms' sales to Nicosia, in place since 1987. According to the authors, this prohibition obliged the Republic of Cyprus in the past to turn to other countries for arms sales, including countries, such as Russia, that pose challenges to US interests around the world. Equally interesting are the following two objectives (among others) of the bill:

- "to support efforts to counter Russian Federation Government interference and influence in the Eastern Mediterranean through increased security cooperation with Greece, Cyprus and Israel, to include intelligence sharing, cyber, and maritime domain awareness."

- And "to support the Republic of Cyprus efforts to regulate its banking industry to ensure that it is not used as a source of international money laundering and encourages additional measures toward that end" (which obviously relates with the accusations against Cyprus of being used by Russian elites for money laundering purposes $)^{23}$.

In case the bill becomes a law, it would provide significant boost to US-Cypriot relations, put US-Turkish relations under close monitoring and set obstacles to further development of Russian-Cypriot relations, at least to the degree that legislation may affect US foreign policy.

\section{Possible Effects on Russian-Cypriot Relations}

\section{Economic Relations}

Economic relations between Russia and $\mathrm{Cy}$ prus flourished after the end of the Cold War, but the actual boost was due to the accession of Cyprus to the European Union in 2004, which rendered Cyprus an attractive business partner, while, according to some observers, put Nicosia in a position to act as Moscow's "Trojan horse" in Brussels. ${ }^{24}$ Russian investments have vastly contributed to the growth of the Cypriot economy in the post-Cold War era, which makes Russia a valuable economic partner for Cyprus. The vibrant Russian community, physically located mainly in the city of Limassol, thrives in various business sectors. ${ }^{25}$ In 2012, when Cyprus was facing severe consequences due to the Eurozone crisis (especially in relation with its overblown banking sector) a Russian loan of EUR2,5 billion rescued Cypriot economy (though later on a bail-in and harsh austerity measures were deemed necessary for Cyprus to remain in the Eurozone) ${ }^{26}$ Furthermore, Cyprus' taxation and legislative framework (reinforced by a network of bilateral agreements, such as a double taxation treaty) acted as the main catalyst for the flow of Russian deposits and foreign direct investments in the island ${ }^{27}$. The business activity conducted by (and related with) the Russian offshore companies registered in Cyprus comprises a significant part of the Cypriot GDP ${ }^{28}$ and it was further enhanced after 2013 by a scheme-launched by the Cypriot government as a measure to tackle the financial crisis-for granting Cypriot (thus EU) citizenship to foreign investors ${ }^{29}$.

However, this activity seems to decline recently, especially since November 2018, when in a circular sent to the Money Laundering Compliance Officers of all Credit, Payment and E-Money Institutions, ${ }^{30}$ the Central Bank of Cyprus provided a new definition of shell companies and urged the interested parties to avoid business relationships with such entities. This led to the closure of many such companies and

23 J. Dempsey, "The Cypriot Euro Crisis is Also About Germany and Russia," Carnegie Europe, March 25, 2013. https:// carnegieeurope.eu/strategiceurope/51282?lang=en. Accessed on May 9, 2019.

${ }^{24}$ M. Leonard, N. Popescu, "A Power Audit of EU-Russia Relations," European Council on Foreign Relations, policy paper, November 2007, 27-31.

${ }^{25}$ On the Russian community in Cyprus and its business activities see "Russia Doing Business in Cyprus 2017: Measuring Quality and Efficiency Survey Report," Cyprus Russian Business Association/EY Cyprus, August 2017.

${ }^{26}$ P. Henley, "The EU's other bailout: How Cyprus turned to Russia," BBC News, June 23, 2012. https://www.bbc.com/ news/world-europe-18541820, accessed on May 17, 2019.

${ }^{27}$ N. Baudet von Gersdorff, "The Cyprus-Russia connection: Implications for the European Union," 2015, 10.13140/ RG.2.1.1263.1202.

${ }^{28}$ H. Smith, "Welcome to Limassolgrad: the city getting rich on Russian money," The Guardian, February 17, 2018. https://www.theguardian.com/world/2018/feb/17/welcome-to-limassolgrad-the-city-getting-rich-on-russian-money, accessed on May 18, 2019.

${ }^{29}$ G. Psyllides, "EU focuses on Cyprus over passport sale concerns," Cyprus Mail, January 23, 2019. https://cyprusmail.com/2019/01/23/president-accuses-eu-of-double-standards-over-golden-visa-programme/, accessed on May 18, 2019.

${ }^{30}$ Central Bank of Cyprus/Eurosystem, 2 November 2018 (Circular Letter). Subject: Shell companies/entities. 
subsequently caused a wave of Russian money exodus from Cyprus. ${ }^{31}$ Russian deposits in Cyprus, which remained at a significant level even after the 2013 bail-in and the collapse of the Cypriot banking system, are currently leaving Cyprus in a growing pace. "The decline recorded within two months, specifically by end of February 2019 was EUR140 million. And compared to one year ago, the overall decline in deposits is at EUR1,34 billion, according to Central Bank data. The same data shows that "total deposits by Russians were EUR11,76 billion by end of 2013, recording a decline of EUR4,95 billion by February 2019"32. These developments are not unrelated with EU measures against moneylaundering, neither with the fact that Nicosia is closely monitored by the US financial crime prevention network, known as FinCEN ${ }^{33}$.

Another sector of paramount importance for Russian-Cypriot bilateral economic relations is tourism. Cyprus is a preferable destination for many Russian tourists because of the sun and the sea, but also because of the Christian Orthodox tradition of the island and its major pilgrimage sites. Russian tourist arrivals in Cyprus increased significantly after the rift in USTurkish relations in 2014-2015, as well as due to the political instability in Egypt during the same period. According to the Cyprus Statistical Service, tourist arrivals from Russia are growing steadily since 2004 . In 2016 we had the biggest annual increase in absolute numbers $(781,634$, compared to 524,853 in 2015). In 2018, the most successful year in the history of Cypriot tourism, arrivals from Russia amounted to 783,631, out of $3,938,625$ overall arrivals $^{34}$. However, there are indications that this tendency is being reversed: Famagusta district, the favourate destination for Russians in Cyprus (especially the Ayia Napa resort) expects $50 \%$ fewer Russian tourists in 2019 and this is partially attributed to the normalisation of Russian-Turkish relations, as well as to the restoration of Egypt's credibility as a tourist destination ${ }^{35}$.

\section{Diplomatic Relations and the Cyprus Problem}

Contrary to the waning economic relations, diplomatic relations seem to remain in good shape. Since 1991, all Cypriot Presidents and Foreign Ministers paid official visits to Russia, while the two countries also maintain significant channels of parliamentary diplomacy. ${ }^{36}$ Moscow has been supporting Nicosia's views on the Cyprus problem, especially in the context of its permanent membership of UN Security Council. For example, in 2004, when then-President Tassos Papadopoulos decided to reject a UN Secretary General's plan for the settlement of the Cyprus problem which was backed by Turkey, the US and the UK, the so-called Annan Plan, Russia stood firmly by his side. Probably the most marking moment for the Greek Cypriots was Russia's use of its veto right on 21 April 2004 to block a resolution that aimed to outline new UN security arrangements that would take effect in Cyprus in case the Greek Cypriots and the Turkish Cypriots approved the Annan Plan in separate referendums, three days later. ${ }^{37}$ It must be underlined that the active support of Kofi Annan's plan and his initiatives for the settlement of the Cyprus problem "strengthened Turkey's image as a source of regional stability, democratization and reform, and Erdoğan's image of being a promoter of democratic pluralism in an Islamic country. This was an important goal in [G. W.] Bush's foreign policy in the aftermath of the Iraq war." ${ }^{\prime 38}$ Therefore, potential

31 "Russian Ambassador: EU sanctions and shell-companies' shutdown raise concerns," Stockwatch, November 16, 2018. https://www.stockwatch.com.cy/en/article/trapezes/russian-ambassador-eu-sanctions-and-shell-companiesshutdown-raise-concerns, accessed on May 14, 2019.

${ }^{32}$ A. Charalambous, "Russians deposits leaving Cyprus amount to $€ 5$ billion," In-Cyprus, April 8, 2019. https://incyprus.com/russians-deposits-leaving-cyprus-amount-to-e5-billion/, accessed on May 14, 2019.

33 Ibid.

${ }^{34}$ Statistical Service, "Arrival of Tourists by Country of Usual Residence, 1980-2018." http://www.cystat.gov.cy/mof/ cystat/statistics.nsf/services_71main_en/services_71main_en?OpenForm\&sub=1\&sel=2, accessed on May 21, 2019.

${ }^{35}$ G. Psyllides, "Slowdown expected in Russian tourism," Cyprus Mail, May 10, 2019. https://cyprus-mail. com/2018/05/10/russian-tourism-could-be-down-as-much-as-50-per-cent-this-year-napa-mayor-says/, accessed on May 14, 2019.

36 "Relations between Russia and Cyprus," Embassy of the Russian Federation in the Republic of Cyprus. https://cyprus.mid.ru/web/cyprus_en/relations-between-cyprus-and-russia, accessed on May 17, 2019.

${ }^{37}$ E. M. Lederer, "Russia Blocks UN Cyprus Resolution," Associated Press, April 21, 2004. D. Papadopoulos, "Tassos Papadopoulos, Russia and the Annan Plan," Cyprus Mail, April 26, 2016. https://cyprus-mail.com/2016/04/26/ tassos-papadopoulos-russia-and-the-annan-plan/, accessed on May 15, 2019.

${ }^{38}$ V. Coufoudakis, Cyprus and International Politics (Nicosia: Intercollege Press, 2007), 131-132. 
ratification of the Annan Plan, which was ultimately rejected by the Greek Cypriots in the referendum, would serve Washington's interests and objectives, in times of US global primacy and hegemonic activity in the Middle East.

To a degree, especially when it comes to the Republic of Cyprus' interests and diplomatic priorities, "Cypriot bilateral relations with Russia are primarily driven by the Cyprus problem." ${ }^{39}$ Russia's traditional support of Greek Cypriot views on the Cyprus problem remains unchanged to this date, despite renewed relations with Turkey. Even in the case of Turkey's actions that aim to halt Cyprus' efforts to explore its Exclusive Economic Zone for natural gas (where Russian interests are not necessarily compatible with the Cypriot ones, as noted above), Moscow's official statements remain supportive of Nicosia's rights. ${ }^{40}$ Russia's stance on the Cyprus problem (and related issues) must be examined under the lens of Moscow's need to maintain its international foothold as a great power. International influence capacity suggests a critical power indicator in diplomatic relations and the Eastern Mediterranean is a region of high geostrategic importance for Moscow. ${ }^{41}$ A factor that facilitates Russia's stance is Cyprus' non-participation to NATO. Despite the strategic realignments described above and calls for Cyprus and NATO to examine a closer relationship, ${ }^{42}$ as long as Turkey does not recognise the Republic of Cyprus (and the Cyprus problem remains unresolved), Ankara would definitely veto a Cypriot bid. Furthermore, due to left-wing AKEL's ${ }^{43}$ sharp disagreement with such a perspective and the latter's position in the internal structure of Cypriot politics, it is rather unlikely that a strong political consensus in favour of an application for full membership or enhanced partnership may be formed (at least not for the time being). Therefore, to the degree that the Eastern Mediterranean is a field where great (and regional) powers strive for influence, Moscow would like to retain its influence over the only European, non-NATO member state in this region.

\section{Cultural Relations}

When it comes to cultural relations, where intergovernmental interaction suggests only one out of many aspects, adaption to international systemic changes is slower and less likely than in economic and diplomatic relations. In order to evaluate this pillar of Russian-Cypriot relations we must examine civil society elements, which contribute to their development. The presence of the Russian community in Cyprus and the flow of hundreds of thousands of Russian tourists per year facilitate (and reinforce) cultural exchanges between the two countries at various levels. We must underline the role of the Russian Center for Science and Culture in Nicosia, which is particularly active in promoting Russian culture in Cyprus. ${ }^{44}$ Certainly though, the most important factor that nurtures these ties is religion. Religion speaks to the civilisational level and suggests an element that may either unify or divide people across national borders. Although this article does not argue that civilisational characteristics may transcend national interests as the most decisive factor in designing foreign policy, there is no doubt that, in some cases, religion suggests an important variable. Usually foreign policy analysts discuss religion in the context of soft power, a term introduced by Joseph Nye meaning the ability to entice and attract, contrary to the coercive nature of hard power. ${ }^{45}$ Religion as an indicator of soft power has been researched mainly in relation with predominantly Muslim countries (like Iran, Saudi Arabia and Turkey) that attempt to capitalise on religious relations in pursuit of political influence in the Islamic (particularly the Arab) world. ${ }^{46}$

\footnotetext{
${ }^{39}$ G. Christou, "Bilateral Relations with Russia and the Impact on EU policy: The Cases of Cyprus and Greece," Journal of Contemporary Eastern European Studies, Vol. 19, No. 2 (June 2011), 230.

40 "President: Turkish EEZ incursion 'a second invasion'," Cyprus Mail, May 6, 2019. cyprus-mail.com/2019/05/06/ cyprus-taking-action-over-turkeys-eez-incursion/, accessed on May 6, 2019.

${ }^{41}$ N. Alexandrova-Arbatova, "Great Powers Involvement in Eastern Mediterranean," Cyprus Center for European and International Affairs, Eastern Mediterranean Policy Note No. 29, August 2018.

42 D. Wilson, "NATO Membership for Cyprus. Yes, Cyprus," Atlantic Council, March 31, 2019. https://www.atlanticcouncil.org/blogs/new-atlanticist/nato-membership-for-cyprus, accessed on April 8, 2019.

${ }^{43}$ The second biggest (and main opposition) political party in Cyprus.

44 http://kyp.rs.gov.ru/en

45 J. S. Nye jr., The Paradox of American Power. Why the World's Only Superpower Can't Go it Alone, (New York: Oxford University Press, 2002), 9. See also J. Haynes, Religious Transnational Actors and Soft Power (London: Routledge, 2016).

${ }^{46}$ For an analysis that incorporates recent developments see P. Mandaville, S. Hamid, "Islam as Statecraft: How Governments Use Religion in Foreign Policy," Foreign Policy at Brookings, November 2018.
} 
As regards religious politics in the Christian Orthodox world, Russia's role as the biggest and most powerful predominantly Orthodox country is of paramount importance. In his influential work on the clash of civilisations, Samuel Huntington argued that "the fault lines of civilisations are replacing the political and ideological boundaries of the Cold War as the flash points for crisis and bloodshed" and underlined the "cultural division of Europe between Western Christianity, on the one hand, and Orthodox Christianity, on the other (...)." ${ }^{\prime 7}$ Russia's use of its Orthodox identity as a soft power indicator is a field that has recently attracted the attention of researchers and policy makers, thus leading to the production of a significant number of publications in English. ${ }^{48}$ However, the literature mainly aims to analyse Russia's religious influence in the post-Soviet world. Regarding Russian-Cypriot relations, the use of soft power indicators for foreign policy purposes remains relatively under-researched. Nevertheless, there is no doubt that the two countries maintain significant religious bonds, therefore mutual soft power indicators are in place. Relations between the Greek Orthodox Church of Cyprus and the Russian Orthodox Church are close and constantly enriched. Indicatively, the Kykkos Monastery, one of the most attractive sites for Russian pilgrims and monks in Cyprus, which maintains relations with Russia since the $18^{\text {th }}$ century, is funding visiting programmes for students and researchers from Russia who wish to visit Cyprus for research purposes, as well as a Modern Greek Language Chair in the Moscow Theologian Academy. ${ }^{49}$ Recently, in March 2017 the President of the Republic of Cyprus, Nicos Anastasiades, inaugurated the first Russian-style church in Cyprus, a few kilometers away from Nicosia. ${ }^{50}$ Another interesting issue is the way the Church of Cyprus handled the rift between the Russian Orthodox Church and the Ecumenical Patriarchate of Constantinople: On 5 January 2019, Ecumenical Patriarch Bartholomew held joint service with the head of the Ukrainian church Metropolitan Epifaniy (in the presence of Ukraine's President Petro Poroshenko) in St. George's Cathedral in Istanbul, where he signed a decree granting "autocephaly" to Ukrainian Church. ${ }^{51}$ The autocephaly marked the Ukrainian Church's split from Moscow's Patriarchate and it was seen as one more episode in the struggle between Constantinople and Moscow for spiritual primacy in the Orthodox world. ${ }^{52}$ The Cypriot Archbishop Chrysostomos II had expressed his readiness to mediate for a commonly accepted solution on the Ukrainian Church's autocephaly..$^{53}$ After the signature of the autocephaly decree the Holy Synod of the Church of Cyprus issued an announcement supporting the Ukrainian Orthodox Church's right to independence, but also underlined that Patriarch Bartholomew should "take into account the 'sensitivities' of Russians whose roots in the faith are found in Ukraine." ${ }^{54}$ This stance of the Church of Cyprus, an autocephalous Greek Orthodox Church closely associated with the Ecumenical Patriarchate, is indicative of its intention to take a balanced position that would not jeopardise relations with Moscow.

\section{Increased Complexity versus Resilience}

Change in international systems, mainly its drivers and outcomes, suggests one of the big questions that theory of international relations

${ }^{47}$ S. P. Huntington, "The Clash of Civilizations?" Foreign Affairs, Vol. 72, No. 3 (Summer, 1993), 22-49, 29-30.

${ }^{48}$ See for example A. Sergunin, L. Karabeshkin, "Understanding Russia's Soft Power Strategy," Politics, Vol. 35 (2015), 347-363. N. Shafiee, E. Fallahi, "The Church and Religious Diplomacy in Russia's Foreign Policy," Journal of Iran and Central Eurasia Studies Vol. 1, No. 1 (Spring 2018), 93-105. A. Dimitrova, M. Frear, H. Mazepus, D. Toshkov, M. Boroda, T. Chulitskaya, O. Grytsenko, I. Munteanu, T. Parvan, I. Ramasheuskaya, "The Elements of Russia's Soft Power: Channels, Tools, and Actors Promoting Russian Influence in the Eastern Partnership Countries," EU-STRAT Working Paper No. 04, July 2017. N. N. Petro, "Russia's Orthodox Soft Power," Carnegie Council, March 23, 2015. https://www.carnegiecouncil.org/publications/articles_papers_reports/727, accessed on May 20, 2019.

${ }^{49}$ C. Kokkinoftas, "Relations between Kykkos Holy Monastery and Russia," Yearbook of the Kykkos Holy Monastery Research Center, Vol. 7 (2006), 281-304, 303 (in Greek).

${ }^{50}$ G. Psyllides, "President opens Cyprus' first Russian-style church," Cyprus Mail, March 27, 2017. https://cyprus-mail. com/2017/03/27/president-opens-cyprus-first-russian-style-church/, accessed on May 21, 2019.

51 "Ukraine Church Granted Independence in Historic Split With Russia," The Moscow Times, January 5, 2019. https://www.themoscowtimes.com/2019/01/05/ukraine-church-granted-independence-in-historic-split-with-russia-a64045, accessed on May 21, 2019.

52 S. Litsas, "Russia in the Eastern Mediterranean: Intervention, Deterrence, Containment," Digest of Middle East Studies, Volume 26, No. 1 (Spring 2017), 67.

53 "Church of Cyprus Prepared to Become Mediator in Settlement of Ukrainian Church Issue," Orthodox Christianity, September 28, 2018. http://orthochristian.com/116069.html, accessed on May 21, 2019.

54 "Cyprus Orthodox Church backs Ukrainian church's independence," Ekathimerini, February 21, 2019. http://www. ekathimerini.com/237926/article/ekathimerini/news/cyprus-orthodox-church-backs-ukrainian-churchs-independence, accessed on May 21, 2019. 
aims to deal with. Kenneth Waltz stressed that international systems undergo internal transformations whenever their structure (namely distribution of capabilities across the major units of the system) changes. ${ }^{55}$ Structural changes are fed by the fact that the capabilities of a system's units tend to grow unevenly. According to Robert Gilpin, uneven growth affects not only the distribution of power at the systemic level, but also state expectations and behavior at the units' level. ${ }^{56}$ Similarly, Paul Kennedy points that uneven rate of growth among different societies, along with technological and organisational breakthroughs which bring a greater advantage to one society than to another, are the drivers of change in relative strengths of the leading nations in world affairs. ${ }^{57}$

As an independent variable that brings about systemic change through the changing distribution of capabilities, uneven growth could vary in intense and impact. A perception of power distribution in a given system, which is subject to the dynamics of uneven growth, could be underpinned (or undermined) by another related factor: prestige. According to Gilpin, "prestige is the reputation for power, and military power in particular. Whereas power refers to the economic, military, and related capabilities of a State, prestige refers primarily to the perceptions of other States with respect to a State's capacities and its ability and willingness to exercise its power." ${ }^{58}$ So, prestige speaks to the sphere of perceptions. It corresponds to what the others believe of a State's capacity and will. Prestige generates legitimacy, namely acceptance of authority, the right of a rule or a ruler to be obeyed, as distinguished from the power to coerce." 59 A State with hegemonic aspirations, that has persuaded its rivals of its superior capacity by showing its muscles (not just having them without making use of them), is more likely to capitalise on its strength. The more it is persuasive of its will to act towards imposing its interests or its favourable version of an international order, the more its rule will be accepted and respected. Conversely, when a hegemonic State's prestige is waning (either due to a real devaluation of its power indicators or a perceived one), or when its decisiveness to impose its will is disputed, its legitimacy is proportionately undermined.
The study of contemporary Eastern Mediterranean and the broader Middle East verifies, to a large degree, the validity of these theoretical assumptions. The structure of the international system is changing due to uneven growth dynamics, which cause respective adaptions at the level of perceptions and prestige. In that sense, US overexpansion and its consequences forced Washington to a strategic withdrawal from the Middle East, which, subsequently, changed the way others saw the US and transformed its prestige accordingly. Consequently, Russia exploited this situation in order to establish its presence and increase its influence in the region, which led to a redistribution of power and triggered a struggle for the formation of a new regional balance of power. In this framework, realignment of interests and reconfiguration of bilateral and multilateral relations was a natural outcome of the changing power distribution and perceptions. If we focus our microscope on bilateral and multilateral relations between the US, Russia, Turkey and Cyprus we may observe two independent variables, which define the direction of the overall set of relationships, which are mutually reinforcing: Turkey's post-Kemalist foreign policy and the degree of tensions between Russia and the US/NATO. It seems that the more Turkey distances itself from its Western allies the more impetus its relations with Russia may gain. On the other hand, the more US-Russian relations worsen, the more Russia is motivated to embrace Turkey aiming to put NATO's internal unity to the test. At the same time, Turkey's independent regional agenda and hegemonic aspirations in the Eastern Mediterranean tends to disturb its relations with regional States. Whether Washington's decision is (or will be) to change its partners in the region, or to try to bring Ankara back on board through a stick-and-carrot strategy, US interests will more or less favor the convergence between Israel, Cyprus and Greece. Moreover, the more Washington is engaged in containing Russia's influence in the region the more its cooperation with these countries will be enhanced. Therefore, we may assume that the more Ankara and Moscow converge and the more Washington and Moscow clash, the more US-Turkish relations will be disturbed and US-Cypriot relations will improve.

\footnotetext{
${ }^{55}$ K. N. Waltz, Theory of International Politics (New York: McGraw-Hill, 1979), 97-98.

${ }^{56}$ R. Gilpin, War and Change in World Politics (Cambridge: Cambridge University Press, 1981), 93.

${ }^{57}$ P. Kennedy, The Rise and Fall of the Great Powers (New York: Vintage, 1987), xv.

58 R. Gilpin, War and Change in World Politics, 30-31.

${ }^{59}$ A. Watson, The Evolution of International Society (New York: Routledge, 1992), 17
} 
Apparently, the ongoing systemic dynamics are not in favour of the Russian-Cypriot relations. This is already evident in the economic pillar. The Russian community is expected to retain its privileged position in the island, however, Russian money exodus will continue as long as Cyprus adjusts with European regulations and is motivated to comply with American calls. This tendency will be enhanced further in case the "Eastern Mediterranean Security and Energy Partnership Act of 2019" becomes a law in the US. Furthermore, Russian-Turkish honeymoon may lead to more tourist waves from Russia to Turkey and to a decrease of tourist arrivals in Cyprus. Other than that, the improving status of this partnership may raise more concerns in Nicosia, such as the potential dangers due to the future functioning of a Russian-made nuclear energy plant in Turkey's southern coast a few kilometers away of Cyprus, which is perceived as a threat to the island's environmental security. ${ }^{60}$

At the diplomatic level, at least for the time being, Russian-Cypriot relations seem to remain in good shape. Russia continues to back Greek Cypriot views on the Cyprus problem and to support Nicosia's right to exploit its offshore energy resources. There is a mutual interest in this matter because, on the one hand, Cyprus would like to keep enjoying Russia's support in the Security Council while, on the other hand, Russia would like to retain some diplomatic leverage on the Republic of Cyprus. This tranquility could be disturbed in the future if the interested parties decide to resume the negotiations for the solution of the Cyprus problem, which are currently frozen. The Cyprus issue is not among Turkey's strategic priorities right now but, in case of a reshuffling in Ankara's agenda, this could change. In that case, Turkey would like to promote a solution in its own terms and that could create a dilemma for Moscow (and
Washington), taking into account the new configuration of interests in the Eastern Mediterranean. We must keep in mind that Washington's active support of energy-related developments, the S- 400 case and the submission of the Eastern Mediterranean Security and Energy Partnership Act of 2019 took place after the last round of negotiations for the Cyprus problem failed. Therefore, it remains unknown how their resumption could play out in relation with the current configuration of relations and interests in the region.

Finally, when it comes to cultural relations, systemic changes do not seem to bring about any impact. Cultural relations are rather dependent on historical and societal factors than on national interests and foreign policy decisions. At the same time, they tend to affect (albeit not drastically) foreign policy decision making through the interaction of soft power indicators. Therefore, we could argue that the cultural factor generates counter-tendencies that mitigate the negative impact of systemic developments on Russian-Cypriot relations.

The evaluation of Russian-Cypriot relations though the examination of possible systemic effects on the pillars of economy, diplomacy and culture, indicates the degree of complexity that currently characterises this traditional partnership. Furthermore, it seems that complexity grows in an increasing pace: the more RussianTurkish relations and US-Cypriot relations develop and the more US-Russian tensions increase, the more Russian-Cypriot relations face obstacles and deadlocks. However, Moscow and Nicosia retain common interests at various levels, while their cultural ties remain strong and immune to developments at the systemic level. In other words, we may expect that the negative effects of the increasing complexity in RussianCypriot relations will be mitigated by the resilience provided by their sustainable foundations.

\section{КИПР И ВЕЛИКИЕ ДЕРЖАВЫ ОЦЕНКА РОССИЙСКО-КИПРСКИХ ОТНОШЕНИЙ В СОВРЕМЕННЫХ УСЛОВИЯХ, СЛОЖИВШИХСЯ В ВОСТОЧНО-СРЕДИЗЕМНОМОРСКОМ РЕГИОНЕ}

\author{
Отнотения между Российской Федерацией \\ и Республикой Кипр традиционно были тесны- \\ ми. Однако некоторые недавние системные со-
}

бытия, похоже, подрывают их прочную основу. В этой статье рассматривается современная международная система и, в особенности, реги-

\footnotetext{
60 "European Parliament votes against Turkey's upcoming nuclear power plant," TRT World, March 13, 2019. https:// www.trtworld.com/turkey/european-parliament-votes-against-turkey-s-upcoming-nuclear-power-plant-24915, accessed on May 23, 2019.
} 
ональная подсистема Восточного Средиземноморья с иелью отслеживания системных изменений, которые могут повлиять на отнотения между исследуемыми странами. Анализ российско-кипрских отношений посвящен потенцииальному Влиянию международных системных изменений на каждый из трех основных

Ключевые слова: системные изменения, распределение власти, национальные интересы, мягкая сила, показатели мягкой силы, чрезмерное расширение, баланс сил, восприятие, вакуум власти элементов: экономические, дипломатические и культурные отношения.

Михалис Контос, доцент кафедры политики и управления Юридического факультета Университета Никосии, Кипр.

\section{Keywords:}

systemic changes, power distribution, national interests, soft power, soft power indicators, overexpansion, balance of power, perceptions, power vacuum 